\title{
Reexamining the Cyclical Behavior of the Relative Price of Investment
}

\author{
Paul Beaudry, Alban Moura ${ }^{\dagger}$ and Franck Portier ${ }^{\ddagger}$ \\ July 2014
}

\begin{abstract}
We document the cyclical behavior of several measures of the relative price of investment goods for the U.S. economy over the last fifty years. Our main result is that there is no robust evidence that this relative price is countercyclical in the data. Furthermore, for the recent (post-Volcker) period, the relative price of investment appears predominantly procyclical. When looking at more disaggregated series, most measures are procyclical, a few acyclical, and only the price of equipment is countercyclical for some periods and measures. The procyclical behavior of the relative price of aggregate investment is also found for the six other countries of the G7.
\end{abstract}

Key Words: Relative price of investment, business cycles

JEL Code: E3

\section{Introduction}

In this paper, we document the cyclical behavior of the relative price of investment. The common wisdom in the macroeconomic profession is that this relative price is countercyclical, reflecting the importance of investment-specific technological shocks in the business cycle. We find surprisingly little support for this view in the data. We summarize our main results in Table 1, where we use three definitions of aggregate investment (total private investment, business investment, household investment), two measures of the price of consumption (the numéraire used to compute relative prices), two measures of the business cycle (output and hours worked), and two samples. For all the measures, the relative price of investment is

\footnotetext{
*Vancouver School of Economics, University of British Columbia and NBER. (paulbe@mail.ubc.ca)

${ }^{\dagger}$ Toulouse School of Economics (Alban.Moura@TSE-fr.eu)

†Toulouse School of Economics and CEPR (Franck.Portier@TSE-fr.eu)
} 
Table 1: Cyclical correlations between relative investment prices and output or hours

\begin{tabular}{clcccc}
\hline \hline Measure & Deflator & Sample & Total Private & Business & Household \\
\hline \multirow{4}{*}{ Corr. with $y$} & Benchmark & $1960-2013$ & -0.10 & -0.18 & 0.02 \\
& Benchmark & $1984-2013$ & 0.12 & 0.05 & $0.15^{\star}$ \\
\cline { 2 - 6 } & Core & $1960-2013$ & 0.04 & -0.05 & 0.13 \\
& Core & $1984-2013$ & $0.38^{\star}$ & $0.35^{\star}$ & $0.37^{\star}$ \\
\hline \multirow{5}{*}{ Corr. with $h$} & Benchmark & $1960-2013$ & 0.05 & -0.13 & 0.16 \\
& Benchmark & $1984-2013$ & $0.36^{\star}$ & $0.27^{\star}$ & $0.33^{\star}$ \\
\cline { 2 - 6 } & Core & $1960-2013$ & 0.22 & 0.07 & $0.29^{\star}$ \\
& Core & $1984-2013$ & $0.60^{\star}$ & $0.57^{\star}$ & $0.54^{\star}$ \\
\hline \hline
\end{tabular}

Note: this table displays correlations of various measures of the relative price of investment with output and hours. The numéraire is the price of personal consumption expenditures on non-durable and services (benchmark) or the same price excluding 'Gasoline and other energy goods' (core). Variables are HP-filtered with smoothing parameter 1600. $A \star$ means that the correlation is significant at $5 \%$.

procyclical over the recent (post-Volcker) period, and almost always significantly so. When considering a longer sample, it is rarely countercyclical and never significantly so. We show in the paper that similar results hold for the other G7 countries. Also, the choice of the consumption price, which has not been discussed in the literature, has important effects on the results: using a core deflator makes the relative price of investment much more procyclical.

The cyclical behavior of the relative price of investment is an indicator of the relative importance of demand and supply shocks in the investment market, an important question given that investment is the most volatile component of output. A long-lasting view, dating back at least to Keynes, emphasizes the role of investment demand by forward-looking entrepreneurs. Modern incarnation of this theory include the literature on news shocks about the future profitability of investment goods, for example Beaudry and Portier [2004], [2011] and Beaudry, Collard, and Portier [2011]. Such models based on demand-driven fluctuations predict a countercyclical relative price of investment. ${ }^{1}$ A more recent branch of the literature, pioneered by Greenwood, Hercowitz, and Huffman [1988] and extended by Fisher [2006] and Justiniano, Primiceri, and Tambalotti [2010], puts forward supply shocks arising from investment-specific changes in technology as important drivers of the cycle. As those shocks affect the efficiency of investment production, they are associated with countercyclical

\footnotetext{
${ }^{1}$ See also Murphy, Shleifer, and Vishny [1989].
} 
movements in the relative price of investment.

The question of the origin of investment fluctuations has regained interest over the last thirty years, Although asset prices boomed in each of those three expansions, the evolution of the relative price of different categories of investment has been less documented, the consensus among macroeconomists being that the relative price of investment is strongly countercyclical because of investment-specific technological shocks. As productivity has become less and less procyclical $^{2}$, investment-specific technology shocks also appear as a powerful way to generate investment booms in DSGE models. For example, the investment-specific technology shock is one of the three main drivers of output fluctuations in Smets and Wouters [2007].

In this paper, we contribute to the debate between these competing theories by establishing the main stylized facts about the cyclicality of the relative price of investment. We adopt a purely descriptive approach based on unconditional correlations between HP-filtered series. $^{3}$ This procedure allows us to discuss issues that have been little studied, such as instability in the cyclical patterns over time or the crucial role of the consumption deflator in shaping the properties of the relative price of investment.

There are already some papers that study the cyclical behavior of the relative price of investment, and the main conclusion so far is that it is countercyclical. Using annual data from 1947 to 1988, Murphy, Shleifer, and Vishny [1989] correlate the prices of consumer durables and producer equipment deflated by the GDP price with the growth rate of the unemployment rate and find negative correlations. Christiano and Fisher [1998] find that both the relative prices of investment, measured as the price of fixed investment plus durable over the price of nondurable goods and services over the 1947-1995 sample, and equipment are countercyclical, while Christiano and Fisher [2003] highlight the puzzling fact that stock market prices are procyclical while the prices of equipment goods are countercyclical. They reconcile this facts in a model with investment-specific technological change and adjustment

\footnotetext{
${ }^{2}$ This fact is documented by Galí and van Rens [2014]. According to McGrattan and Prescott [2014], the countercyclicality of labor productivity during the 1990s technology boom and in the Great Recession is likely to be the consequence of a mismeasurement of GDP. If investment in intangible capital is not counted as investment but as intermediate consumption, it is left out of GDP. As this investment is procyclical, GDP in underestimated in expansion and overestimated in recession, creating a spurious countercyclicality of labor productivity and TFP.

${ }^{3}$ The use of VARs would allow to study conditional correlations, at the cost of potentially controversial identification issues. In this paper, we aim at being as close as possible from an agnostic description of the data.
} 
costs to the growth rate of investment (and not capital). Greenwood, Hercowitz, and Krusell [2000] also document a countercyclical relative price of investment, but consider only the relative price of equipment. Fisher [2006] considers four relative investment prices, constructed using a consumption deflator corresponding to nondurable and service consumption, the service flow from consumer durables, and government consumption. Specifically, he uses the Gordon [1990] and Cummins and Violante [2002] (GCV) equipment deflator, the price of total investment constructed by merging the GCV deflator with the NIPA deflators for nonresidential and residential structures, consumer durables, and government investment, as well as the NIPA counterparts to these two prices. The sample period is 1955-2000. The cyclical correlation of the relative equipment price with output is negative, while the one of total investment (not reported) is "somewhat weaker, but still significantly negative" (p. 428). By considering a longer sample, clarifying the role of the consumption deflator, and documenting how the cyclical patterns of relative investment prices vary over time, we update these results and reach different conclusions.

The paper is organized as follows. In Section 2, we describe the time series used in our empirical analysis. Section 3 contains our main results about the cyclical behavior of the relative price of investment. As explained above, in addition to the usual aggregate national account series, we clarify the properties of disaggregated investment series over different subperiods, and using different deflators. We also study other G7 countries. Section 4 concludes.

\section{Data and methodology}

In this section, we present the U.S. time series we use in our benchmark empirical analysis. We need to define investment, its price, as well as the price of the relevant numéraire. Throughout, we rely on standard national accounting sources, namely the Bureau of Economic Analysis' NIPA. Appendix A provides a comprehensive description of our dataset. We also describe our empirical strategy. 


\subsection{Dataset}

We follow Fisher [1999] in considering a broader definition of investment that the BEA's. We define total private investment as the sum of fixed investment and consumer expenditures on durable goods. On the other hand, we exclude changes in private inventories and government investment from our aggregate measure. We decompose total private investment into business investment and household investment. Business investment corresponds to the BEA's nonresidential investment measure: it includes firms' expenditures on structures, producer equipment, and intellectual property products. Household investment corresponds to the sum of residential investment and consumer expenditures on durables. For our benchmark analysis, we use NIPA data and follow the BEA's chain aggregation method to construct aggregates when needed. Later, we consider alternative investment measures that have been constructed in the literature to control for a potential lack of quality adjustment by the BEA.

For our baseline numéraire, we take the index of consumer expenditures on nondurable goods and services. Therefore, we compute the relative investment price by dividing the investment price by the price index for nondurable and service consumption. Below, we show that the choice of this numéraire is a crucial input in the analysis of the cyclicality of the relative price of investment by considering an alternative consumption price excluding energy goods.

Our sample runs from 1960Q1 to 2013Q4, and we consider results based on a sample split in the early 80's. Indeed, as discussed by Fisher [2006], that time coincides with significant changes in the relative investment price's average rate of decline (which accelerates, from $-0.9 \%$ per year in the 1960-1983 sample to $-1.7 \%$ per year after 1984 for total private investment), the conduct of monetary policy (1983 is the end of Paul Volcker's first tenure as chairman of the Federal Reserve, which was largely devoted to fighting inflation), and macroeconomic stability (beginning of the Great Moderation). Moreover, as mentioned in the introduction, investment booms and busts seem more prevalent after 1983 than before. To deal with all these issues in a simple fashion, we let the first sample end in 1983Q4 and the second start in 1984Q1. Our conclusions are not sensitive to reasonable variations in this break date.

Table 2 reports nominal GDP shares accounted for by the various components of in- 
Table 2: Aggregate investment measures: Nominal GDP shares

\begin{tabular}{cccc}
\hline \hline & $1960-2013$ & $1960-1983$ & $1984-2013$ \\
\hline Total private investment & 25.29 & 25.23 & 25.35 \\
Business investment & 12.35 & 12.00 & 12.64 \\
Structures & 3.42 & 3.89 & 3.06 \\
Equipment & 6.36 & 6.43 & 6.30 \\
Intellectual property rights & 2.57 & 1.67 & 3.28 \\
Household investment & 12.94 & 13.24 & 12.71 \\
Durable goods & 8.41 & 8.54 & 8.31 \\
Residential & 4.53 & 4.70 & 4.41 \\
\hline \hline
\end{tabular}

vestment, which are very stable across subperiods. The broadest investment measure, total private investment, accounts for one fourth of nominal GDP. It can be in turn decomposed into business and household investments for one half each. Within business investment, equipment is the most important component, before structures and intellectual property products. Within household investment, expenditures on durable goods represent twice as much as residential investment.

Figure 1 plots log per-capita investment quantity series together with their HP trends. Shaded bands represent NBER recession dates. Unsurprisingly, the long-run evolution of investment quantities is dominated by the presence of upward trends. This is especially true of aggregate measures such as total private investment, business investment, or household investment. As can be seen by looking at the component series, the rise in total private investment comes from the strong upward trends in producer equipment and household durables. On the other hand, structures and residential investment display no clear growth pattern, but instead varying upward and downward trends over shorter subperiods.

Contrasting the remarkable stability in nominal GDP shares with the apparent heterogeneity in quantity series, it must be that relative prices for different investment measures have evolved differently over the 1960-2014 sample. This is indeed what we see from Figure 2, which provides log relative investment prices. Mirroring the large rise in equipment and durables quantities, the relative prices of these two classes of investment goods display pronounced negative trends. This fact was first documented by Gordon [1990] and is often interpreted as signaling investment-specific technological change (Greenwood, Hercowitz, and 
Krusell [1997]). On the contrary, the relative prices of structures and residential investment are non trending. However, the relative prices of aggregate investment measures such as total private investment inherit downward trends from the prices of equipment and durables.

\section{$2.2 \quad$ Empirical approach}

The above discussion shows that the long-run properties of both investment quantity and relative price series are dominated by trends and low-frequency fluctuations. These phenomenon have little to do with business cycles and prevent a cyclical analysis based on the series in levels. Therefore, we use the Hodrick-Prescott with a smoothing parameter 1600 to isolate the business-cycle components of the series and report instantaneous and dynamic correlation patterns between these cyclical components and an indicator of the business cycle. ${ }^{4}$ We consider two such measures: the cyclical components of real per-capita GDP and per-capita hours worked in the private nonfarm business sector. We include hours worked because they provide an alternative index of the business cycle that is not as affected by productivity shocks as output is.

\section{Business cycle analysis}

This section presents our main empirical findings about the cyclical behavior of the relative price of investment. As far as quantities are concerned, it is well-established and robust that investment is procyclical and more volatile than output, so that we delegate the corresponding discussion to Appendix C.

\subsection{Benchmark analysis for the U.S.A.}

We start with our benchmark analysis of U.S. data. The top rows in Tables 3 and 4 display the contemporaneous correlations between the relative prices of investment and our two measures of the cycle, over both the full sample and the two subsamples. Figures 3 , 4, and 5 provide the corresponding cross-correlograms between the relative investment prices and the output quantity.

\footnotetext{
${ }^{4}$ Our findings are robust to using instead a $\mathrm{BP}(6,32)$ filter to isolate cyclical components of the data.
} 
Table 3: Cyclical correlations between relative investment prices and output

\begin{tabular}{cccccccccc}
\hline \hline Deflator & Sample & TPI & BI & HI & EI & SI & IPR & RI & DG \\
\hline \multirow{3}{*}{ Benchmark } & $1960-2013$ & -0.10 & -0.18 & 0.02 & $-0.31^{\star}$ & 0.10 & 0.06 & $0.50^{\star}$ & -0.03 \\
& $1960-1983$ & $-0.24^{\star}$ & $-0.31^{\star}$ & -0.07 & $-0.31^{\star}$ & -0.16 & -0.01 & $0.55^{\star}$ & -0.01 \\
& $1984-2013$ & 0.12 & 0.05 & 0.15 & $-0.31^{\star}$ & $0.39^{\star}$ & 0.14 & $0.52^{\star}$ & -0.05 \\
\hline \multirow{3}{*}{ Core } & $1960-2013$ & 0.04 & -0.05 & 0.13 & -0.23 & 0.17 & $0.25^{\star}$ & $0.54^{\star}$ & 0.12 \\
& $1960-1983$ & -0.16 & $-0.28^{\star}$ & -0.01 & $-0.31^{\star}$ & -0.11 & 0.10 & $0.53^{\star}$ & 0.04 \\
& $1984-2013$ & $0.38^{\star}$ & $0.35^{\star}$ & $0.37^{\star}$ & -0.06 & $0.49^{\star}$ & $0.42^{\star}$ & $0.63^{\star}$ & $0.23^{\star}$ \\
\hline \hline
\end{tabular}

Note: a star indicates that the correlation is significant at the 5-percent level. TPI: Total private investment, BI: Business investment, HI: Household investment, EI: Equipment, SI: Structures, IPR: Intellectual property rights, RI: Residential, DG: Durables.

Table 4: Cyclical correlations between relative investment prices and hours

\begin{tabular}{cccccccccc}
\hline \hline Deflator & Sample & TPI & BI & HI & EI & SI & IPR & RI & DG \\
\hline \multirow{3}{*}{ Benchmark } & $1960-2013$ & 0.05 & -0.13 & 0.16 & $-0.38^{\star}$ & $0.32^{\star}$ & 0.08 & $0.59^{\star}$ & -0.11 \\
& $1960-1983$ & $-0.25^{\star}$ & $-0.47^{\star}$ & -0.02 & $-0.51^{\star}$ & -0.13 & -0.17 & $0.61^{\star}$ & $-0.23^{\star}$ \\
& $1984-2013$ & $0.36^{\star}$ & $0.27^{\star}$ & $0.33^{\star}$ & $-0.21^{\star}$ & $0.63^{\star}$ & $0.25^{\star}$ & $0.60^{\star}$ & 0.03 \\
\hline \multirow{3}{*}{ Core } & $1960-2013$ & 0.22 & 0.07 & $0.29^{\star}$ & $-0.26^{\star}$ & $0.40^{\star}$ & $0.33^{\star}$ & $0.65^{\star}$ & 0.09 \\
& $1960-1983$ & -0.13 & $-0.40^{\star}$ & 0.07 & $-0.49^{\star}$ & -0.05 & 0.01 & $0.62^{\star}$ & -0.15 \\
& $1984-2013$ & $0.60^{\star}$ & $0.57^{\star}$ & $0.54^{\star}$ & 0.05 & $0.72^{\star}$ & $0.51^{\star}$ & $0.69^{\star}$ & $0.30^{\star}$ \\
\hline \hline
\end{tabular}

Note: a star indicates that the correlation is significant at the 5-percent level. TPI: Total private investment, BI: Business investment, HI: Household investment, EI: Equipment, SI: Structures, IPR: Intellectual property rights, RI: Residential, DG: Durables. 
Looking at Figure 3, the picture that emerges is clearly not one of strong countercyclicality. Among disaggregated investment measures, the only component whose relative price is significantly negatively correlated with output is equipment. Over the full sample 1960-2013, it has a contemporaneous correlation of -0.31 with output and -0.23 with hours worked. Otherwise, the relative prices of structures and durables are roughly acyclical, with respective (non significant) contemporaneous correlations with output of 0.10 and -0.03 . The relative price of structures, though, is significantly procyclical when the business cycle is measured by hours worked, with an instantaneous correlation of 0.32 . The relative price of residential investment is strongly procyclical, with an instantaneous correlation of 0.50 with GDP and 0.59 with hours. Turning to aggregate series, business investment is slightly countercyclical (not significantly so), while household investment is acyclical. As a whole, we find small and non significant correlations between the relative price of total private investment and output $(-0.10)$ and hours worked (0.05) along the cycle over the full sample.

\subsection{Sample instability and structural change}

It is instructive to compare the cyclical properties of relative investment prices over the two subsamples, 1960-1983 and 1984-2013. As mentioned in the introduction, there is ample evidence that the U.S. economy experienced some kind of structural break in the early 80's, and the narrative of business cycles in the second subperiod is often one of booms and busts driven by asset price fluctuations and investment in capital goods. Therefore, we would expect some changes in the correlation patterns.

Figures 4 and 5 compare the cross-correlograms of the different relative investment prices with output across the two subperiods. Over the first subsample, relative investment prices are more countercyclical: with the exception of residential investment, all relative prices are negatively correlated with contemporaneous output. In particular, the prices of both business and total private investment are significantly countercyclical, with contemporaneous correlations with output of -0.31 and -0.24 . A similar pattern arises when the cycle is measured using hours worked. Over the first sample, the data are therefore consistent with a leading role for investment-specific technological shocks.

As expected from the narrative of the last three cycles, these correlation patterns are 
reversed over the second subsample. In particular, the relative prices of total private investment, business investment, and household investment all turn procyclical. Their instantaneous correlations with GDP range from 0.05 to 0.15 and are not significant, but as shown in Table 4, the correlations with hours worked are much larger, ranging from 0.27 to 0.36 , and all significant. We interpret these patterns as signaling a larger role for demand shocks in generating investment fluctuations in the 1984-2013 period.

To summarize our analysis so far, we find that only the relative price of equipment out of the four main subcomponents of total private investment is always significantly countercyclical. Below, we show that this result largely depends on the definition of the consumption deflator. We also document that, in the 1984-2013 sample in which investment fluctuations are prevalent, relative prices of the three aggregate investment measures (total private, business, household) are procyclical.

\subsection{Consumption deflator and energy prices}

One aspect that has received little attention in the literature is the choice of the consumption deflator. For example, Fisher [1999] deflates investment prices by the price index of nondurable and service consumption, while Fisher [2006] uses a broader price index based on nondurable and service consumption, the service flow from consumer durables, and government consumption as numéraire. Alternatively, Liu, Waggoner, and Zha [2011] deflate their investment price by the GDP price index.

It is important to understand how the choice of the deflator affects the cyclical behavior of the relative investment price. In particular, the treatment of energy prices appears to be of first importance, because its cyclical pattern has changed quite a lot. Indeed, energy prices were countercyclical in the 70's and early 80's because of the successive oil shocks, and became procyclical afterwards as energy prices were mainly pulled by the world economic growth and the uprising of emerging economies. Consider for instance the behavior of $p_{c} / p_{c, \text { core }}$, the ratio between our benchmark consumption price constructed from nondurables and services, and its core counterpart obtained by excluding the energy component. Its correlation with output along the cycle, equal to 0.10 over the $1960-1983$ subsample, jumps to 0.56 in the 1984-2013 subsample. As $p_{c}$ has become more procyclical because of its energy component, it follows 
that $p_{i} / p_{c}$ has mechanically become more countercyclical. Because such a changing pattern is is not directly related with changes in the respective strength of shocks to investment demand and supply, it seems relevant to remove it by computing the correlation between output and $p_{i} / p_{c, \text { core }}$.

This is what we do in Figures 6, 7, and 8, while instantaneous correlations are displayed in Tables 3 and 4. Over the full 1960-2013 sample, the relative price of total private investment becomes acyclical when compared to output (contemporaneous correlation of 0.04), but turns procyclical when compared to hours (instantaneous correlation equal to 0.22 , although not significant). Among disaggregated series, only the relative equipment price shows a negative correlation of -0.23 with GDP, but it is not significant. Looking at the second subsample, we now obtain a very clear picture: for all categories of investment except equipment, and for all aggregate investment measures, the relative prices are significantly procyclical: the contemporaneous correlations with GDP range from 0.23 for durables to 0.63 for residential, and those with hours worked are even larger.

\subsection{Quality adjustment issues}

Following Gordon's [1990] systematic analysis of the quality bias in official NIPA price indexes, the literature on investment-specific technology shocks has generally relied on qualityadjusted investment price series. This is the case, for instance, in Greenwood, Hercowitz, and Huffman [1988] and Fisher [2006]. We briefly show here that our findings remain valid when the relative price of investment is constructed from such quality-adjusted series.

We consider three quality-adjusted investment price series. The first two are from Cummins and Violante [2002], who directly extend Gordon's original measures of the quality bias in official price indexes, and correspond to equipment and business investment. The series are annual, ranging from 1947 to 2000, and we construct their quarterly counterparts by cubic spline interpolation. The third one has been kindly provided to us by Tao Zha and is referred to in Liu, Waggoner, and Zha [2011] under the code TornPriceInv4707CV. It is computed as a weighted average index from four quality-adjusted price indexes: private nonresidential structures investment, private residential investment, private nonresidential equipment and software, personal consumption expenditures on durable goods. 
Table 5: Cyclical correlations between relative investment prices and output - Qualityadjusted series

\begin{tabular}{ccccc}
\hline \hline Deflator & Sample & CV Equipment & CV Business Inv. & LWZ Total Inv. \\
\hline \multirow{3}{*}{ Benchmark } & $1960-2000$ & $-0.48^{\star}$ & -0.17 & -0.16 \\
& $1960-1983$ & $-0.61^{\star}$ & $-0.30^{\star}$ & $-0.22^{\star}$ \\
& $1984-2000$ & 0.10 & $0.23^{\star}$ & 0.04 \\
\hline \multirow{3}{*}{ Core } & $1960-2000$ & $-0.42^{\star}$ & -0.09 & -0.11 \\
& $1960-1983$ & $-0.56^{\star}$ & -0.19 & $-0.21^{\star}$ \\
& $1984-2000$ & 0.15 & $0.26^{\star}$ & 0.15 \\
\hline \hline
\end{tabular}

Note: CV: Cummins and Violante's (2002) series, interpolated with a cubic spline to obtain quarterly series. LWZ: Liu, Waggoner, and Zha's (2011) series.

Table 6: Cyclical correlations between relative investment prices and hours — Qualityadjusted series

\begin{tabular}{ccccc}
\hline \hline Deflator & Sample & CV Equipment & CV Business Inv. & LWZ Total Inv. \\
\hline \multirow{3}{*}{ Benchmark } & $1960-2000$ & $-0.41^{\star}$ & -0.06 & $-0.22^{\star}$ \\
& $1960-1983$ & $-0.62^{\star}$ & $-0.26^{\star}$ & $-0.45^{\star}$ \\
& $1984-2000$ & $0.24^{\star}$ & $0.39^{\star}$ & $0.23^{\star}$ \\
\hline \multirow{2}{*}{ Core } & $1960-2000$ & $-0.32^{\star}$ & 0.04 & -0.14 \\
& $1960-1983$ & $-0.53^{\star}$ & -0.11 & $-0.43^{\star}$ \\
& $1984-2000$ & $0.30^{\star}$ & $0.43^{\star}$ & $0.35^{\star}$ \\
\hline \hline
\end{tabular}

Note: CV: Cummins and Violante's (2002) series, interpolated with a cubic spline to obtain quarterly series. LWZ: Liu, Waggoner, and Zha's (2011) series. 
Table 7: Correlations between relative investment prices and output in the G6 countries

\begin{tabular}{lcccccc}
\hline \hline Country & Can & Ger & Fra & GB & Ita & Jap \\
\hline Corr. & $0.19^{\star}$ & 0.10 & 0.12 & $0.25^{\star}$ & 0.02 & $0.18^{\star}$ \\
P-value & 0.03 & 0.3 & 0.06 & 0.00 & 0.84 & 0.00 \\
\hline \hline
\end{tabular}

Note: samples vary across countries.

Tables 5 and 6 report the contemporaneous business-cycle correlations between those quality-adjusted price measures and output or hours worked. Clearly, our main conclusions still hold: (i) Only the quality-adjusted relative price of equipment is significantly countercyclical in the full sample. (ii) While relative investment prices are countercyclical in the 1960-1983 sample, they all turn procyclical afterwards. Therefore, the empirical facts we document are not an artefact caused by mismeasurement of quality improvements in capital goods.

\subsection{Other G7 countries}

We end our empirical analysis by examining time series for the six other G7 countries, namely Canada, France, Germany, Great Britain, Italy and Japan. Because all countries do not publish national accounts as complete as the NIPA, we proceed in a simple and relatively crude way. For each country, we first obtain time series for nominal and real private consumption and nominal and real fixed investment. ${ }^{5}$ Then, we compute the consumption and investment deflators by dividing nominal series by real ones. Eventually, we define the relative price of investment as the ratio of these two deflators. Samples are 1981Q1-2012Q1 for Canada, 1955Q1-2013Q4 for France, 1991Q1-2012Q4 for Germany, 1955Q1-2012Q4 for Great-Britain, 1981Q1-2011Q2 for Italy, and 1955Q1-2013Q4 for Japan.

Contemporaneous correlations between the cyclical components of these relative investment price and output series are provided in Table 7. All correlations are positive, and significantly so in Canada, Great Britain, and Japan (and almost in France). Therefore, we conclude again that data do not support the view that the relative price of aggregate investment is countercyclical in developed economies.

\footnotetext{
${ }^{5}$ Appendix B provides a detailed description of the data.
} 


\section{Conclusion}

We document the cyclical properties of the relative price of investment. We emphasize three results: (i) There is no empirical evidence that the relative price of aggregate investment is significantly countercyclical. (ii) It is significantly procyclical for the recent period, as well as the relative prices of all its subcomponents, with the exception of equipment price which is statistically acyclical. (iii) The procyclicality of relative investment prices is stronger when computed taking hours worked as a measure of the cycle, or when the consumption price is purged for energy price fluctuations.

What do these results suggest for macroeconomic theory? Definitively not that investment specific technology shocks are irrelevant, but surely that an agnostic examination of the data does not validate the common view that they are the main driver of investment fluctuations and that shocks to the demand for investment are of second order importance. ${ }^{6}$ Designing a general equilibrium model featuring these two classes of shocks and letting them compete in a structural estimation exercise therefore seems a fruitful avenue for future research.

\section{References}

Beaudry, P., F. Collard, and F. Portier (2011): "Gold rush fever in business cycles," Journal of Monetary Economics, 58(2), 84-97.

Beaudry, P., And F. Portier (2004): "An exploration into Pigou's theory of cycles," Journal of Monetary Economics, 51(6), 1183-1216.

(2011): “A Gains from Trade Perspective on Macroeconomic Fluctuations," NBER Working Papers 17291, National Bureau of Economic Research, Inc.

Brockwell, P. J., And R. A. Davis (1991): Time Series: Theory and Methods. SpringerVerlag, New York, NY, 1991 edn.

\footnotetext{
${ }^{6}$ We find some support for this view in the results of Justiniano, Primiceri, and Tambalotti [2011], who evaluate the role of two distinct investment shocks in an estimated New-Neoclassical Synthesis business-cycle model. The first shock is an investment-specific technology perturbation, identified with the relative price of investment, while the second shock affects the transformation of savings into the future capital input. Estimation results suggest that this second shock, affecting the marginal efficiency of investment, is the main driver of investment fluctuations. Importantly, this shock does not imply a countercyclical relative price of investment.
} 
Christiano, L. J., And J. D. M. Fisher (1998): "Stock Market and Investment Goods Prices: Implications for Macroeconomics," Working Paper Series WP-98-6, Federal Reserve Bank of Chicago.

(2003): "Stock Market and Investment Goods Prices: Implications for Macroeconomics," NBER Working Papers 10031, National Bureau of Economic Research, Inc.

Cummins, J. G., and G. L. Violante (2002): "Investment-Specific Technical Change in the US (1947-2000): Measurement and Macroeconomic Consequences," Review of Economic Dynamics, 5(2), 243-284.

Fisher, J. D. (1999): "The new view of growth and business cycles," Economic Perspectives, Federal Reserve Bank of Chicago, 23, 35-56.

_ (2006): "The Dynamic Effects of Neutral and Investment-Specific Technology Shocks," Journal of Political Economy, 114(3), 413-451.

Galí, J., and T. van Rens (2014): "The Vanishing Procyclicality of Labor Productivity," Working Papers 489, Barcelona Graduate School of Economics.

Gordon, R. (1990): Measurement of Durable Goods Prices. University of Chicago Press, Chicago.

Greenwood, J., Z. Hercowitz, and G. Huffman (1988): "Investment, Capacity Utilisation, and the Real Business Cycle," The American Economic Review, 78, 402-417.

Greenwood, J., Z. Hercowitz, and P. Krusell (1997): "Long-Run Implications of Investment-Specific Technological Change," American Economic Review, 87(3), 342-62.

— (2000): "The role of investment-specific technological change in the business cycle," European Economic Review, 44(1), 91-115.

Justiniano, A., G. E. Primiceri, and A. Tambalotti (2010): "Investment shocks and business cycles," Journal of Monetary Economics, 57(2), 132-145.

(2011): "Investment Shocks and the Relative Price of Investment," Review of Economic Dynamics, 14(1), 101-121. 
Liu, Z., D. F. WaGgoner, And T. Zha (2011): "Sources of macroeconomic fluctuations: A regime-switching DSGE approach," Quantitative Economics, 2(2), 251-301.

McGrattan, E. R., and E. C. Prescott (2014): "A Reassessment of Real Business Cycle Theory," Staff Report 494, Federal Reserve Bank of Minneapolis.

Murphy, K. M., A. Shleifer, and R. W. Vishny (1989): "Building Blocks of Market Clearing Business Cycle Models," in NBER Macroeconomics Annual 1989, Volume 4, NBER Chapters, pp. 247-302. National Bureau of Economic Research, Inc.

Smets, F., And R. Wouters (2007): "Shocks and Frictions in US Business Cycles: A Bayesian DSGE Approach," American Economic Review, 97(3), 586-606.

Whelan, K. (2002): "A Guide to U.S. Chain Aggregated NIPA Data," Review of Income and Wealth, 48(2), 217-33.

\section{A Data sources and construction for the U.S.A.}

This appendix describes both the data sources and the construction of the actual time series we use in the empirical analysis.

\section{A.1 Original series}

Our primary data sources are the Bureau of Economic Analysis' NIPA tables. Specifically, we use Tables 1.1.3, 1.1.4, and 1.1.5 to obtain the NIPA estimates for, respectively, quantity indices, price indices, and nominal series for the following variables: Gross domestic product (line 1), Personal consumption expenditures on durable goods (line 4), Personal consumption expenditures on nondurable goods (line 5), Personal consumption expenditures on services (line 6), Nonresidential investment (line 9), Investment in structures (line 10), Equipment investment (line 11), Intellectual property products (line 12), Residential investment (line 13). From Tables 2.3.3, 2.3.4, and 2.3.5, we similarly get quantity, price, and nominal series for the subcomponents of personal consumption expenditures on nondurable goods (lines 912). We obtain total population from Table 7.1 (line 18). Finally, hours worked are the BLS measure for Nonfarm business sector total hours, which we normalize by the population. 


\section{A.2 Constructing aggregate investment series}

We consider the following aggregate investment measures:

Business Investment $=$ Nonresidential Investment

$$
=\text { Structures }+ \text { Equipment }+ \text { Intellectual Property Products }
$$

Household Investment $=$ Durable Goods + Residential Investment,

Total Private Investment $=$ Business Investment + Household Investment.

We compute nominal series for these aggregates by summing the nominal values of their subcomponents. To construct quantity and price series, we use the BEA's chain aggregation approach. We illustrate the method with household investment. ${ }^{7}$ Letting $D_{t}$ and $R_{t}$ denote the BEA quantity indexes for expenditures on durable goods and residential investment and $P_{t}^{D}$ and $P_{t}^{R}$ denote the corresponding BEA price indexes, we construct the quantity index $H I_{t}$ and the price index $P_{t}^{H I}$ as follows:

- For some reference date $T$, normalize $H I_{T}=1$. Without loss of generality, we set $T=1$ in our computations.

- For all other dates, set $H I_{t}=H I_{t-1} \times Q_{t}$, where $Q_{t}$ is the following Fisher index:

$$
Q_{t}=\sqrt{\frac{P_{t-1}^{D} D_{t}+P_{t-1}^{R} R_{t}}{P_{t-1}^{D} D_{t-1}+P_{t-1}^{R} R_{t-1}} \times \frac{P_{t}^{D} D_{t}+P_{t}^{R} R_{t}}{P_{t}^{D} D_{t-1}+P_{t}^{R} R_{t-1}} .}
$$

- Given the quantity index $H I$, define the price index $P^{H I}$ by

$$
P_{t}^{H I}=\frac{P_{t}^{D} D_{t}+P_{t}^{R} R_{t}}{H I_{t}}
$$

By construction, the product of the quantity and price indexes for a given aggregate is equal to the corresponding nominal series at all dates. We use the same method to construct business investment series by chaining original NIPA quantity and price indexes, and total private investment series by chaining business investment with household investment.

\footnotetext{
${ }^{7}$ See Whelan [2002] for a systematic discussion of the BEA chain aggregation methodology.
} 


\section{A.3 Constructing relative investment prices}

We consider two measures of the consumption price: a price index for nondurable and service consumption obtained by chaining the corresponding NIPA series, and its core counterpart obtained by excluding the 'Gasoline and other energy goods' (Tables 2.3.3, 2.3.4, and 2.3.5, line 11) component. For any investment measure and a given consumption price index, we then define the relative investment price as

$$
\text { Relative Investment Price }=\frac{\text { Investment Price Index }}{\text { Consumption Price Index }} .
$$

\section{B Data sources and construction for other G7 coun- tries}

For all G7 countries other than the U.S., we use series for real Gross domestic product, real and nominal Private final consumption expenditure, and real and nominal Gross fixed capital formation. We compute the consumption and investment deflators, $P_{c}$ and $P_{i}$, by dividing the nominal aggregates by real ones. Finally, we compute the relative price of investment as $P_{i} / P_{c}$.

For Canada, France, Germany and Great-Britain, data are extracted from the FRED database, and samples are respectively 1981Q1-2012Q1, 1955Q1-2013Q4, 1991Q1-2012Q4 and 1955Q1-2012Q4. Real series are in chained 2002 Canadian Dollars for Canada, chained 2005 Euros for France and Germany and chained 2009 Pounds for Great Britain.

In the FRED database, samples are much shorter for Italy and Japan (respectively 1991Q1-2013Q4 and 1994Q1-2013Q4), so that we turn to alternative sources. We obtain Italian data from Istat.it (http://dati.istat.it), with real series expressed in chained 2000 Euros. We obtain Japan data data from the Cabinet Office Home Page (http://www.esri.cao.go.jp). One difficulty is that the real series in chained 2005 Yen only go back to 1994Q1. Historical series can be obtained for the period 1955Q1-2001Q1, but with a 1980 base for real ones. Furthermore, none of the real series is seasonally adjusted. For each variable, we construct a full sample series by merging the two original sources, adjusting the level of the chained 2005 Yen series to make sure that both original series share the same average over their period of overlap, namely 1994Q1-2001Q1. To deal with seasonality, we filter real GDP with 
a bandpass filter removing fluctuations of periods less than or equal to 5 quarters. Because the relative price is a ratio, it does not need further adjustment since seasonal frequencies are eliminated. Because of this complex and potentially hazardous treatment of the data, it is useful to note that for the seasonally adjusted chained 2005 series only, the correlation is 0.26 (p-value .02), compared to 0.18 (p-value 0.00) with the extended sample.

\section{Cyclical properties of investment quantities in the U.S.A.}

As those properties are already well documented and fairly stable over time, we report them only for our full sample 1960Q1-2013Q4.

The first column in Table 8 shows the volatilities of investment quantities relative to real GDP over the business cycle ${ }^{8}$. Unsurprisingly, all investment series are much more variable than GDP. Total private investment is about three times as volatile as output, and household investment is more volatile than business investment. Among disaggregated series, residential investment is the most variable, with a standard deviation more than six times larger than that of GDP at business cycle frequencies. Intellectual property rights is much less variable than other investment components, which is largely due to the specificities of immaterial production.

Turning to the dynamic link between investment and GDP, Figure 9 provides cross-

\footnotetext{
${ }^{8}$ As usual, we compute relative volatilities by dividing the standard deviation of the cyclical component of log per-capita investment series by the standard deviation of the cyclical component of log real per-capita GDP.
}

Table 8: Aggregate investment measures: Business-cycle volatility

\begin{tabular}{ccc}
\hline & $\sigma_{i} / \sigma_{y}$ & $\sigma_{r p i} / \sigma_{y}$ \\
\hline \hline Total private investment & 3.10 & 0.60 \\
Business investment (nonresidential) & 3.07 & 0.61 \\
Structures & 4.16 & 1.13 \\
Equipment & 4.13 & 0.79 \\
Intellectual prop & 1.55 & 0.46 \\
Household investment & 4.27 & 0.67 \\
Durable goods & 2.82 & 0.62 \\
Residential & 6.54 & 1.00 \\
\hline \hline
\end{tabular}


correlograms between investment and output quantities over the business cycle. Specifically, the figure plots the correlation between the cyclical components of investment quantity at date $t+j$ and GDP quantity at date $t$. Shaded bands represent asymptotic 95-percent confidence bands for estimated cross-correlations assuming a true correlation of zero ${ }^{9}$. As expected, all components of investment are strongly procyclical, with contemporaneous correlations with output ranging from 0.47 for structures to 0.90 for total private investment. All are statistically different from zero. Notice that business investment lags the cycle by one quarter since the maximum correlation is between business investment in $t+1$ and GDP in $t$, while household investment leads by one quarter since the maximum correlation is between household investment in $t-1$ and GDP in $t$. These phase shifts come from structures on the one hand, which lag the cycle by four quarters, and residential investment on the other, which leads by one quarter. Those individual phase shifts are masked when considering total private investment, whose cycle is exactly synchronized with that of GDP.

\section{Asymptotic distribution of sample cross-correlations}

In this section, we provide the asymptotic approximation we use to construct confidence bands for sample cross-correlations between HP-filtered series, taking serial correlation into account.

We adopt the following framework. Let $X_{t}$ and $Y_{t}$ be two stationary MA processes with respective innovations $\epsilon_{t}^{X}$ and $\epsilon_{t}^{Y}$. In our applications, $X_{t}$ and $Y_{t}$ represent the cyclical components of HP-filtered quantity or price series. Let $\rho_{X}(j)=\operatorname{corr}\left(X_{t}, X_{t+j}\right)$ and $\rho_{Y}(j)=\operatorname{corr}\left(Y_{t}, Y_{t+j}\right)$ denote the autocorrelation functions of $X_{t}$ and $Y_{t}$. Also, let $\rho_{X Y}(j)=$ $\operatorname{corr}\left(X_{t}, Y_{t+j}\right)$ denote the cross-correlation function between $X_{t}$ and $Y_{t}$ and $\widehat{\rho}_{X Y}(j)$ be its sample counterpart computed from a sample of size $T$. Assume that $\left\{\epsilon_{t}^{X}\right\}$ and $\left\{\epsilon_{t}^{Y}\right\}$ are independent at all leads and lags, so that the distribution is constructed under the null of zero correlation between $\left\{X_{t}\right\}$ and $\left\{Y_{t}\right\}$. Then, theorem 11.2.2 in Brockwell and Davis [1991] implies that

$$
\sqrt{T} \widehat{\rho}_{X Y}(j) \rightarrow_{d} N(0, V), \quad V=\sum_{h=-\infty}^{\infty} \rho_{X}(h) \rho_{Y}(h) .
$$

\footnotetext{
${ }^{9}$ We estimate the asymptotic variances of sample cross-correlations taking serial correlation into account. See Appendix D.
} 
In practice, we replace $V$ by a consistent kernel-based estimator given by

$$
\widehat{V}=\sum_{h=-T+1}^{T-1} K\left(\frac{h}{q(T)}\right) \widehat{\rho}_{X}(h) \widehat{\rho}_{Y}(h),
$$

where $K($.$) is the Bartlett kernel and q(T)$ is a bandwidth function. Conformably with the econometric literature, we set $q(T) \approx T^{1 / 3}$ to optimally trade estimation bias and variance. 


\section{E Figures}


Figure 1: Aggregate investment measures: Quantities, 1960-2013

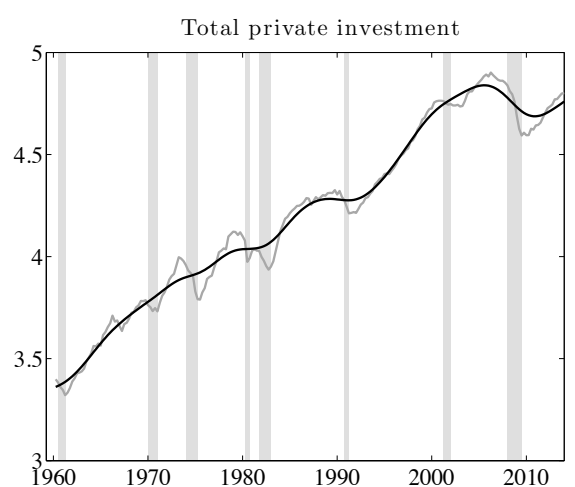

Business investment
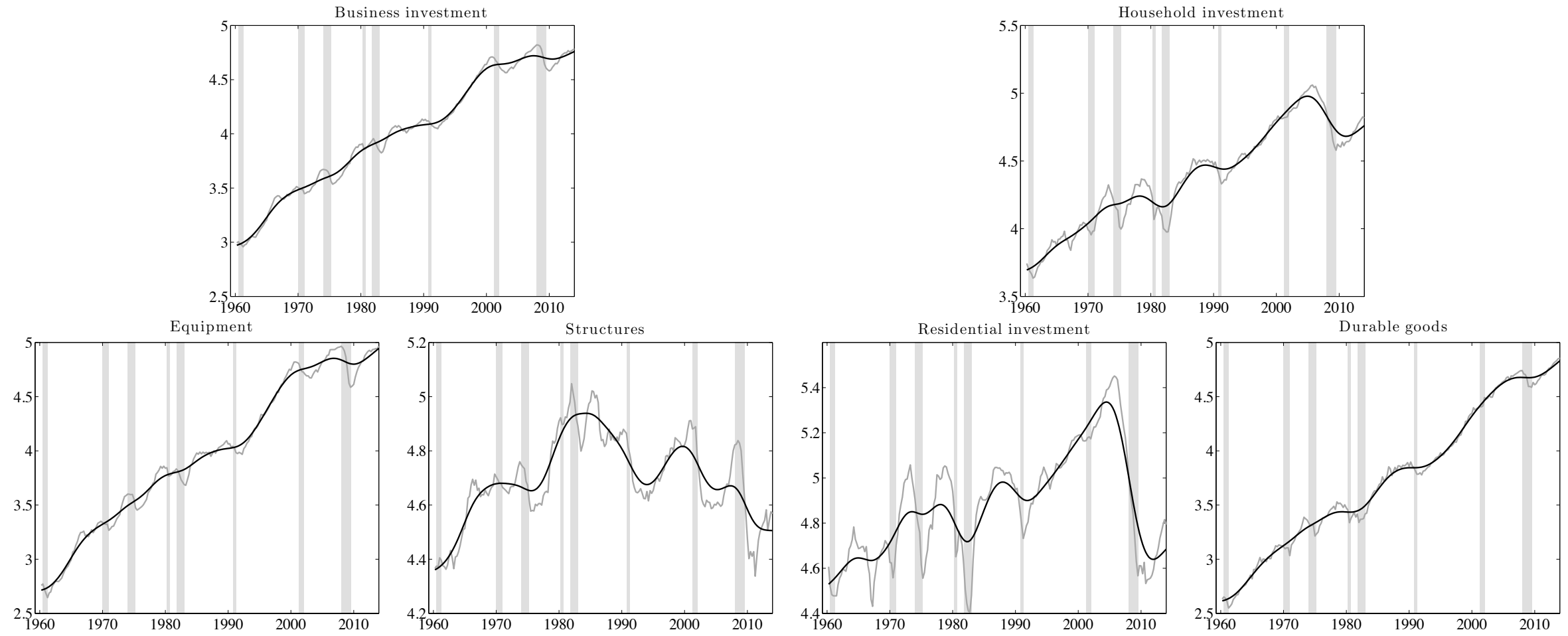
Figure 2: Aggregate investment measures: Relative prices, 1960-2013

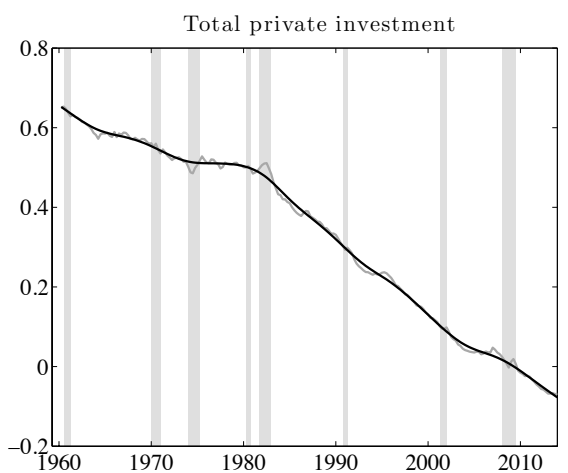

Business investmen
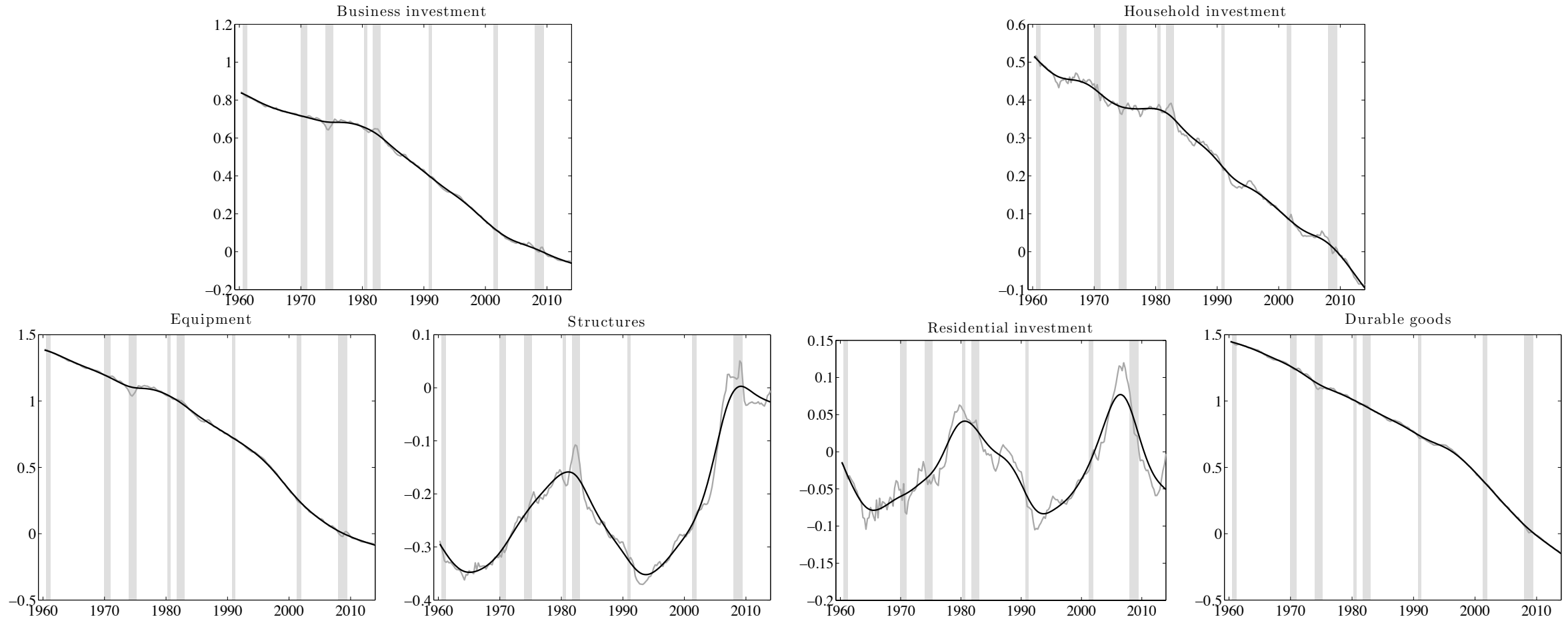
Figure 3: Dynamic correlations between relative investment prices in $t+j$ and GDP quantity in $t, 1960-2013$
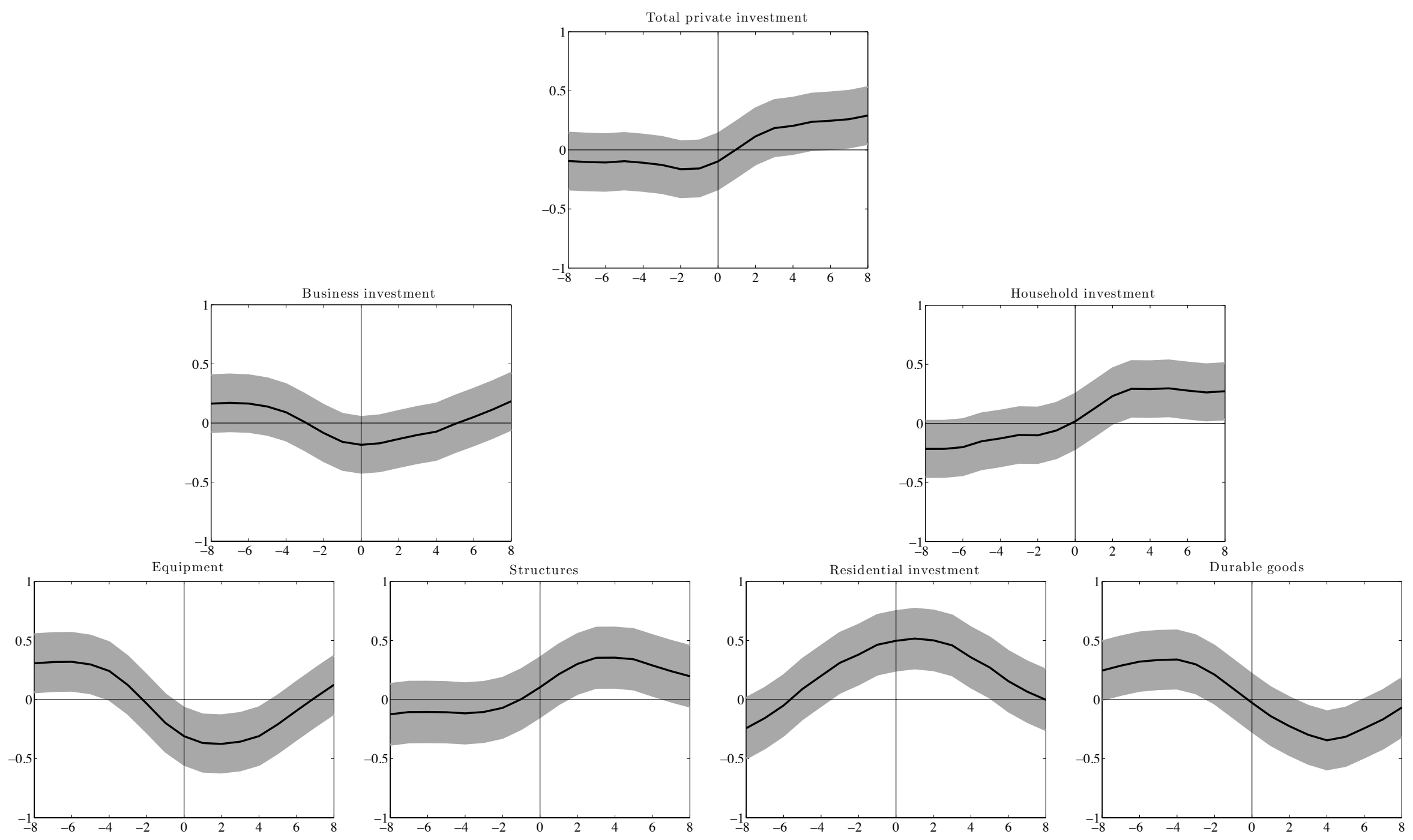
Figure 4: Dynamic correlations between relative investment prices in $t+j$ and GDP quantity in $t, 1960-1983$
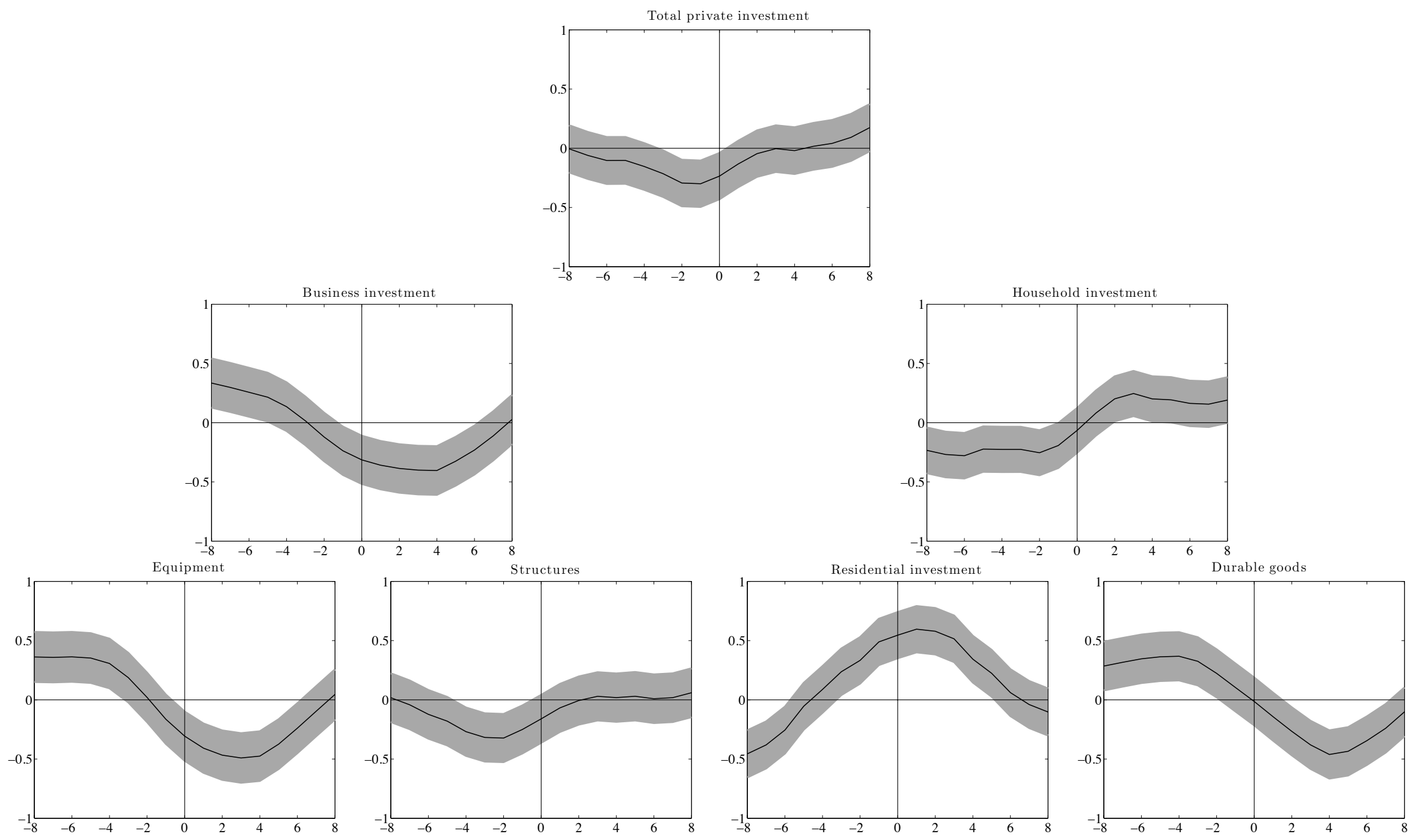


$$
\approx \approx=
$$




$$
\therefore \approx
$$


Figure 7: Dynamic correlations between relative investment prices in $t+j$ and GDP quantity in $t$, Core deflator, $1960-1983$
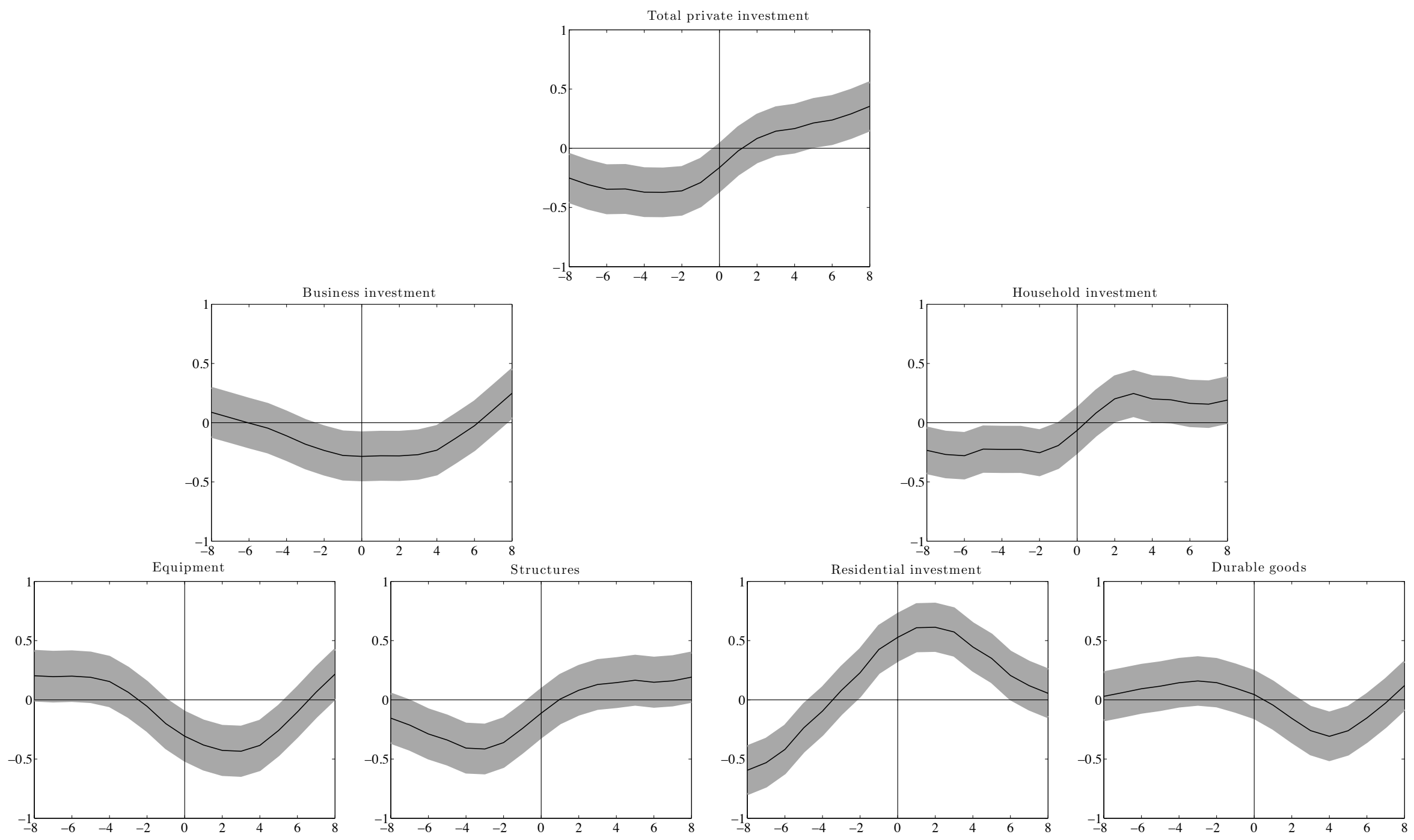


$$
\hat{A n a}
$$




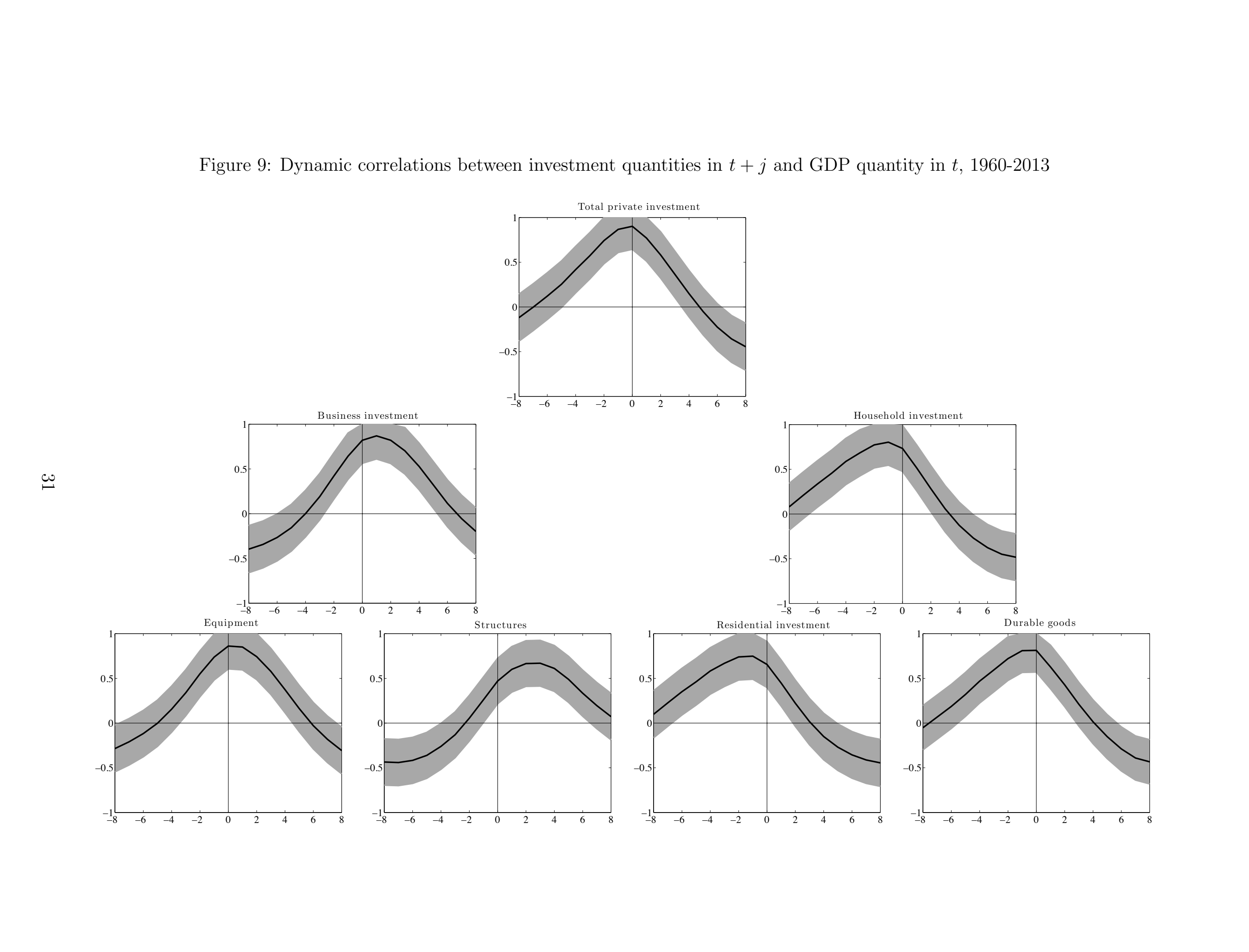

